\title{
CINNARIZINE LIQUID SOLID COMPACTS: PREPARATION EVALUATION
}

\author{
SREENIVAS PATRO SISINTHY*, SHUBBANESWAREI SELLADURAI \\ School of Pharmacy, Faculty of Health and Medical Sciences, Taylor's University, Malaysia \\ Email: sreenivaspatro.sisinthy@taylors.edu.my
}

Received: 03 Oct 2018, Revised and Accepted: 19 Nov 2018

\begin{abstract}
Objective: The objective of this research was to formulate cinnarizine tablets using the liquid-solid compact technique to enhance its solubility and dissolution rate.

Methods: Cinnarizine liquid-solid compacts were formulated using propylene glycol as the non-volatile solvent, Neusilin US2 as the carrier material, Aerosil 200 as the coating material and croscarmellose sodium as the disintegrant. The interaction between drug and excipients were characterized by Fourier-transform infrared spectroscopy (FTIR) and differential scanning calorimetry (DSC) studies. Different batches of liquid, solid compacts were prepared by using varying carrier-coating excipient ratio and different concentration of liquid medication. Flow parameters such as bulk density, tapped density, Carr's Index, Hausner's Ratio as well as an angle of repose were used to test the flowability of the powder blend. The liquidsolid compacts were produced by direct compression method and were evaluated for tests such as weight variation, drug content, hardness, thickness, friability, wetting time, disintegration time as well as the in vitro dissolution studies.
\end{abstract}

Results: The results of the preformulation studies of liquisolid compacts showed acceptable flow properties. The results of FTIR and DSC studies showed that there is no drug-excipient interactions. The different $\mathrm{R}$ values and concentrations were found to have a marked effect on the dissolution profile. Formulations with higher carrier: coating ratio (R-value) and lower drug concentrations displayed a better dissolution profile. The percentage of drug release of F3 with an R-value of 20 and a drug concentration of $10 \%$ was found to be $88.11 \%$ when compared to the conventional marketed tablet which released only $44.07 \%$ at the end of $2 \mathrm{~h}$.

Conclusion: From this research, it is inferred that liquid-solid technique is a promising and effective approach that can be used to enhance the dissolution rate of cinnarizine.

Keywords: Cinnarizine, Liquid-solid compact, Solubility

(C) 2019 The Authors. Published by Innovare Academic Sciences Pvt Ltd. This is an open access article under the CC BY license (http://creativecommons.org/licenses/by/4.0/) DOI: http://dx.doi.org/10.22159/ijap.2019v11i1.30109

\section{INTRODUCTION}

In pharmaceutical formulation and development, drug solubility is an important factor as it is one of the major determinants for oral bioavailability. The poor dissolution rate of water-insoluble drugs remains as a significant issue confronting the pharmaceutical industries. A large number of new chemical entities which have high potential to be developed as useful drugs have failed to reach the public merely due to the poor dissolution rate which results in unsatisfactory bioavailability. An orally administered drug must be insolubilized state and be able to cross the gastrointestinal tract (GIT) membrane to show its therapeutic effects [1]. The therapeutic effect of a drug relies on the bioavailability which is highly dependent on the solubility factor as well as the dissolution rate of the drug. Most of the poorly soluble drugs tend to be eliminated from the GIT before getting absorbed into the bloodstream [2].

Recently, liquid-solid technology is becoming more popular as one of the promising solubility enhancement technique developed by in improving the dissolution profile of the poorly soluble drugs [3]. By using this newly developed technique, it is possible to convert liquid medication into a dry and free-flowing powder just by using simple blending with the suitable carrier and coating materials [4]. A carrier material is basically a porous material with satisfactory absorption properties while the coating material usually made up of highly adsorptive particle which coats the wet carrier particle and converts the formulation into a dry powder form [5].

In this study, cinnarizine is used as a model drug as it is a poorly soluble drug which is classified under BCS Class II by having low aqueous solubility and high permeability. Cinnarizine belongs to antihistamines class of drugs, and it is known to promote cerebral blood flow. It is commonly prescribed for motion sickness. Due to its poor solubility, the therapeutic efficacy of cinnarizine is being limited. Hence, the objective of this research was to improve the solubility of cinnarizine by employing liquid-solid compact technique with the aim of enhancing its dissolution and subsequent bioavailability.

\section{MATERIALS AND METHODS}

Cinnarizine was a gift sample from Kotra Pharma (M) Sdn. Bhd., Malaysia. Polyethylene Glycol 400 and Propylene Glycol was purchased from Merck (Germany) while Tween 20, Tween 80, Span 20 and Span 80, Neusilin US2 and Silica (Aerosil 200) and croscarmellose sodium were purchased from SIME Scientific and lastly, Cremophor RH 40 was purchased from BASF (Germany).

\section{Methods}

\section{Solubility studies}

The solubility of cinnarizine was assessed in different non-volatile solvents such as Tween 20, Tween 80, Span 20, Span 80, polyethylene glycol-400, propylene glycol, Cremophor, and distilled water. $2 \mathrm{ml}$ of each non-volatile solvent was taken in screw cap vials ( $5 \mathrm{ml}$ ) with $100 \mathrm{mg}$ of drug and kept in a water bath shaker at $37{ }^{\circ} \mathrm{C}$ for $48 \mathrm{~h}$. Later, each vial was centrifuged at 6000rpm for $20 \mathrm{~min}$. Appropriate dilution of the filtered solution was done using methanol, and the UV absorbance was measured at $254 \mathrm{~nm}$ wavelength. The concentration of a dissolved drug is determined using the standard equation [6].

\section{Angle of slide}

In evaluating the liquid retention potential of carrier and coating material angle of a slide is used as the parameter. The weighed amount of carrier and coating material was placed on one end of a shiny metal plate. Then, this end was slowly raised until the plate with the horizontal surface formed an angle at which the sample was about to slide. The experiment was done in triplicate and the average of the angle of the slide was calculated [7]. 
Calculation of flowable liquid retention potential of carrier material (ФCA) and coating material (ФCO)

Using mortar and pestle, $1 \mathrm{~g}$ of carrier material (Neusilin US2) was mixed with the increasing quantity of non-volatile solvent (propylene glycol). For each admixture containing a constant amount of carrier material and a specific amount of non-volatile solvent, angle of slide was measured using the methods mentioned above. Using the following equation, the liquid retention potential of carrier material was calculated. Angle of slide corresponding to $33^{\circ}$ is determined as optimal flow behavior.

$$
\Phi C A=\frac{\text { Weight of liquid solvent }(\mathrm{mg})}{\text { Weight of carrier material(mg) }}
$$

The above procedures were exactly repeated by using Aerosil 200 as the coating agent in order to calculate the flowable liquid retention potential of coating material and the equation used to calculate is shown below.

$$
\Phi С 0=\frac{\text { Weight of liquid solvent }(\mathrm{mg})}{\text { Weight of coating material }(\mathrm{mg})}
$$

\section{Calculation of $R, L_{f}$ and amount of carrier and coating materials}

The loading factor $\left(\mathrm{L}_{\mathrm{f}}\right)$ was calculated using the values derived from liquid retention potential of carrier and coating material which corresponds to the angle of $33^{\circ}$. The formula used to calculate the loading factor is shown below [8-10].

$$
\mathrm{Lf}=\Phi C A+\Phi C O\left(\frac{1}{\mathrm{R}}\right)
$$

where $\mathrm{R}=$ Carrier to coating material ratio

The amount of the carrier material required was calculated using the formula below:

$$
\mathrm{Q}=\frac{\mathrm{W}}{\mathrm{L}_{\mathrm{f}}}
$$

$\mathrm{Q}=$ Amount of carrier material

\section{$\mathrm{W}=\mathrm{Weight}$ of the liquid medication}

The ratio between the weight of the carrier material (Q) and weight of coating material (q) is represented by $R$. The value of $R$ is fixed as 5, 10 and 20. Hence, the formula used to calculate the weight of the coating material needed is shown in the formula below:

$$
R=\frac{Q}{q}
$$

\section{Pre-compression studies}

The different formulations were evaluated for the following properties such as angle of repose, bulk density, tapped density, Hausner's ratio, Carr's index [11].

\section{Preparation of cinnarizine liquid-solid compacts}

Cinnarizine was initially dispersed in the propylene glycol with constant stirring using mortar and pestle until a homogeneous drug solution/suspension was obtained. Then the mixture of a carrier (Neusilin US2) and coating material (Aerosil) which were calculated based on the R values $(5,10$ and 20$)$ and Lf values was added to the above liquid medication. After complete incorporation of the liquid medication to the carrier and coating material, $6 \% \mathrm{w} / \mathrm{w}$ of croscarmellose sodium as the disintegrant was added to the mixture and mixed thoroughly. After the final liquid-solid formulation has been produced, the blend was compressed into tablets using rotary

\begin{tabular}{|c|c|c|c|c|c|c|c|c|c|}
\hline $\begin{array}{l}\text { Formu } \\
\text { lation }\end{array}$ & $\begin{array}{l}\text { Cinnarizine } \\
\text { (mg) }\end{array}$ & $\begin{array}{l}\text { Propylene } \\
\text { glycol } \\
\text { (mg) }\end{array}$ & $\begin{array}{l}\text { \% Drug } \\
\text { concentration } \\
\text { in propylene glycol }\end{array}$ & $\begin{array}{l}\text { Loading } \\
\text { factor } \\
\text { (Lf) }\end{array}$ & $\mathbf{R}$ & $\begin{array}{l}\text { Neusilin } \\
\text { (Q) } \\
\text { (mg) }\end{array}$ & $\begin{array}{l}\text { Aerosil } \\
200(q) \\
(\mathrm{mg})\end{array}$ & $\begin{array}{l}\text { Croscarmellose } \\
\text { sodium } \\
\text { (mg) }\end{array}$ & $\begin{array}{l}\text { Formulation } \\
\text { weight } \\
\text { (mg) }\end{array}$ \\
\hline F1 & 25 & 225 & 10 & 1.139 & 5 & 219.50 & 43.90 & 30.80 & 522.20 \\
\hline $\mathrm{F} 2$ & 25 & 225 & 10 & 1.027 & 10 & 243.43 & 24.34 & 31.07 & 548.84 \\
\hline F3 & 25 & 225 & 10 & 0.971 & 20 & 257.46 & 12.87 & 31.22 & 551.55 \\
\hline $\mathrm{F} 4$ & 25 & 100 & 20 & 1.139 & 5 & 109.75 & 21.95 & 15.40 & 272.10 \\
\hline F5 & 25 & 100 & 20 & 1.027 & 10 & 121.71 & 12.17 & 15.53 & 274.41 \\
\hline F6 & 25 & 100 & 20 & 0.971 & 20 & 128.73 & 6.44 & 15.61 & 275.78 \\
\hline
\end{tabular}
tablet press machine with $12 \mathrm{~mm}$ round and flat punch with a compression force that provides acceptable tablet hardness [12-14]. The final formulation of solid liquid compacts is shown in table 1.

Table 1: Formulation of liquid solid compacts

*Each formulation $6 \% \mathrm{w} / \mathrm{w}$ of Croscarmellose sodium

\section{Post-compression studies}

In order to evaluate the prepared liquid-solid compacts, several quality control tests such as weight variation, hardness, thickness, friability, wetting time, drug content uniformity, disintegration, and dissolution test were carried out [15-17].

\section{In vitro dissolution studies}

Dissolution studies were performed for the all the six prepared formulations (F1-F6) as well as for the conventional marketed formulation (F7). The in vitro dissolution behaviors were assessed using the USP rotating paddle Electrolab Dissolution Tester (TDT08L). The dissolution media $(0.1 \mathrm{~N} \mathrm{HCl})$ was kept at $37 \pm 0.5^{\circ} \mathrm{C}$ and a rotation speed of $50 \mathrm{rpm}$ was maintained. Once optimal conditions were achieved, the formulations were placed into the media. $5 \mathrm{ml}$ aliquots were withdrawn at predetermined time intervals $(10,20$, $30,40,60,80,100$ and $120 \mathrm{~min})$. The withdrawn samples were replaced with an equal amount of fresh dissolution media to maintain sink conditions. The samples collected were filtered using a $0.45 \mathrm{~mm}$ Millipore nylon filter and analyzed using a UV-Vis spectrophotometer at a maximum wavelength of $254 \mathrm{~nm}$.

\section{Fourier-transform infrared spectroscopy (FTIR)}

FTIR study is carried out for the identification of the pure drug as well as to determine the chemical interaction between the drug and excipients used in the formulation. 2-3 mg of samples were prepared and the analysis was done based on Attenuated Total Reflectance (ATR) method. The spectrum of a pure drug is compared with the spectrum of the physical mixture of drug with the excipients such as croscarmellose sodium, Neusilin US2, Aerosil as well as Propylene Glycol which were incorporated in the formulation. The spectra were scanned over the wave number range of 4000 to $650 \mathrm{~cm}^{-1}$ [18].

\section{Differential scanning calorimetry (DSC)}

Initially, DSC thermogram for cinnarizine was obtained to confirm the purity of the drug. The expected peak was in the range of 118$122{ }^{\circ} \mathrm{C}[19,20]$ which shows the melting point of cinnarizine. DSC thermograms for liquid-solid preparations was obtained as well. The DSC aluminum cells were used as a sample holder and blank DSC aluminum cell was used as the reference. Samples ranging from 2-5 mg was weighed and used for DSC analysis. Thermograms for all the samples were observed over the range of $20{ }^{\circ} \mathrm{C}-160{ }^{\circ} \mathrm{C}$ at the scanning rate of $10^{\circ} \mathrm{C} / \mathrm{min}$ in a nitrogen atmosphere [21].

\section{RESULTS AND DISCUSSION}

\section{Solubility studies}

Solubility plays an integral part in this research as higher solubility of cinnarizine in the liquid vehicle will lead to higher dissolution rate since the drug will be molecularly dispersed. [22]. According to the 
results shown in fig (1), a solubility of cinnarizine appears to be significantly higher in propylene glycol compared to other nonvolatile solvents. The solubility of cinnarizine in propylene glycol was found to be $24.8 \pm 0.8 \mu \mathrm{g} / \mathrm{ml}$. Hence, propylene glycol has been selected as the appropriate liquid solvent to be incorporated in producing the solid liquid compacts.

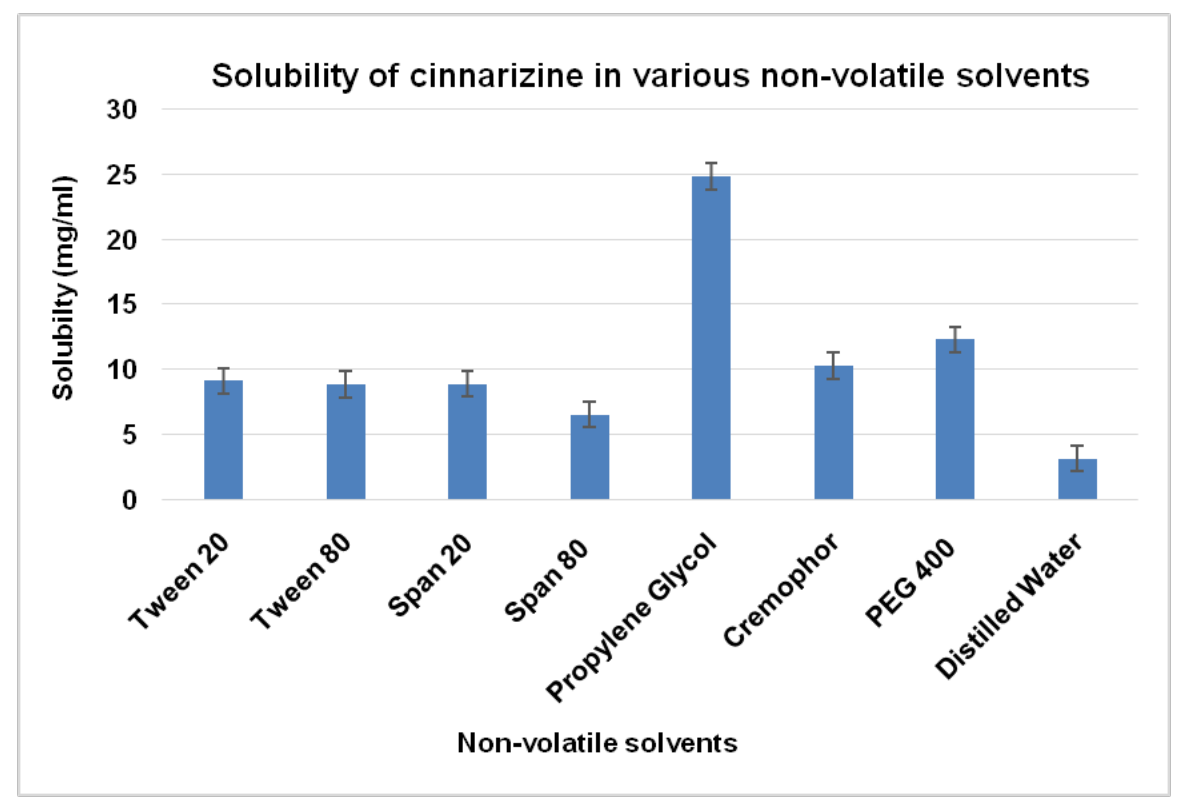

Fig. 1: Solubility data of cinnarizine in various non-volatile solvents, (data expressed in mean \pm SD (n=3), SD standard deviation)

\section{Determination loading factor $\left(\mathrm{L}_{\mathrm{f}}\right)$}

The flowable liquid retention potential of carrier material and coating material were determined from the slopes of the graphs as mentioned in fig (2) and fig (3). The loading factor for different $R$ values was determined by incorporating these values into the following equation:

$$
\mathrm{L}_{\mathrm{f}}=\Phi C A+\Phi C O\left(\frac{1}{\mathrm{R}}\right)
$$

$\mathrm{L}_{\mathrm{f}}=0.915+1.118\left(\frac{1}{\mathrm{R}}\right)$

\begin{tabular}{ll}
\hline $\mathbf{R}$ & $\mathbf{L}_{\mathbf{f}}$ \\
\hline 5 & 1.139 \\
10 & 1.027 \\
20 & 0.971 \\
\hline
\end{tabular}

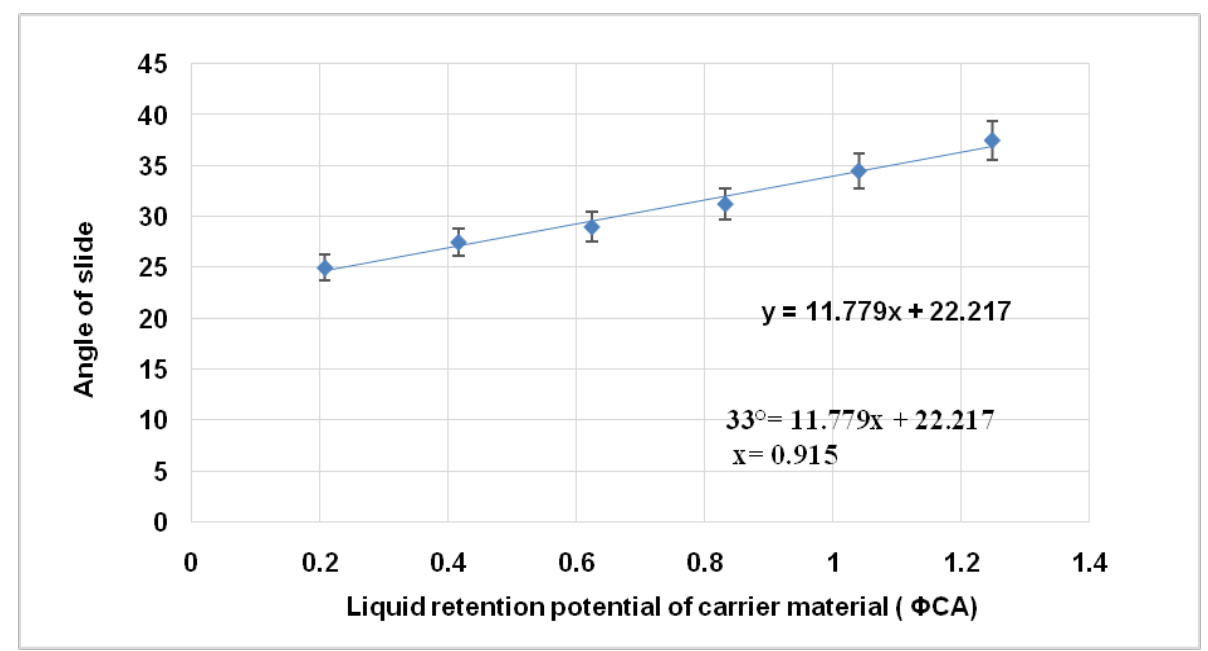

Fig. 2: Graph determining the flowable liquid retention potential of carrier material (Neusilin US2) that corresponds to the $33^{\circ}$. (Data expressed as a mean $\pm S D, n=3$ )

\section{Pre-compression studies}

Liquid-solid formulations is based on the conversion of liquid formulation into a powder with good flowability and compressibility. Hence, testing the parameters such as bulk density, tapped density, Carr's Index, Hausner's ratio as well as an angle of repose is crucial. The results of the precompression studies are shown in the table (2). From the tests that has been done, it is clear that the R-value affects the flowability of the powder blend as the formulations with higher $\mathrm{R}$-value $(\mathrm{R}=20)$ which are the F3 and F6 has better flow properties.

The concentration of the formulation also affects the flowability of the powder blend. It has been found better flowable and compressible powder system has been achieved by the least concentrated formulation that needs a higher amount of carrier material, which leads to high tablet weight. 


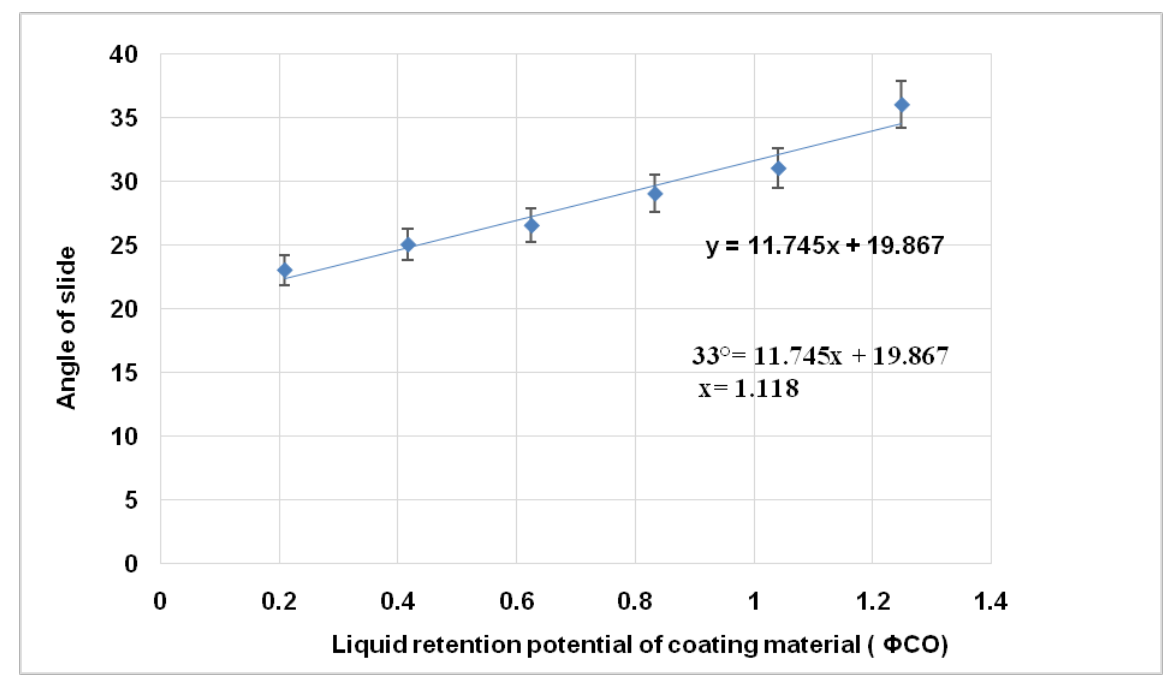

Fig. 3: Graph determining the flowable liquid retention potential of coating material (Aerosil 200) that corresponds to the $33^{\circ}$, (data expressed as a mean $\pm S D, n=3$ )

Table 2: Pre-compression results

\begin{tabular}{|c|c|c|c|c|c|}
\hline \multirow[t]{2}{*}{ Formulation } & \multicolumn{5}{|c|}{ Pre-compression parameters } \\
\hline & Bulk density $\left(\mathrm{g} / \mathrm{cm}^{3}\right)$ & Tapped density $\left(\mathrm{g} / \mathrm{cm}^{3}\right)$ & Carr's index (\%) & Hausner's ratio & Angle of repose $\left({ }^{\circ}\right)$ \\
\hline F1 & $0.252 \pm 0.001$ & $0.317 \pm 0.002$ & $20.505 \pm 0.154$ & $1.258 \pm 0.036$ & $38.40 \pm 0.363$ \\
\hline F2 & $0.277 \pm 0.002$ & $0.346 \pm 0.001$ & $19.942 \pm 0.343$ & $1.249 \pm 0.006$ & $38.29 \pm 0.395$ \\
\hline F3 & $0.299 \pm 0.004$ & $0.372 \pm 0.003$ & $19.623 \pm 0.432$ & $1.244 \pm 0.007$ & $37.92 \pm 0.582$ \\
\hline $\mathrm{F} 4$ & $0.285 \pm 0.002$ & $0.346 \pm 0.001$ & $17.630 \pm 0.340$ & $1.214 \pm 0.005$ & $39.03 \pm 0.137$ \\
\hline F5 & $0.291 \pm 0.002$ & $0.354 \pm 0.001$ & $17.796 \pm 0.797$ & $1.216 \pm 0.012$ & $38.20 \pm 0.375$ \\
\hline F6 & $0.295 \pm 0.004$ & $0.353 \pm 0.002$ & $16.431 \pm 0.093$ & $1.196 \pm 0.001$ & $38.40 \pm 0.605$ \\
\hline
\end{tabular}

(Results were expressed in mean $\pm \mathrm{SD}, \mathrm{n}=3$ )

\section{Post-compression studies}

The results of the post-compression studies are shown in table (3). Based on the results obtained, all the formulations passed the weight variation, drug content uniformity, and disintegration test as the results lie within the acceptable range based on the British Pharmacopeia limits. Tablets (F1, F2, and F3) with a lower concentration $(10 \%)$ which corresponds to the higher tablet weight has larger hardness compared to the tablets (F4, F5, F6) having a higher concentration (20\%). F1, F2 and F3 passed the friability test as they lie within the approved range of less than $1 \%$. The friability of F4, F5, and F6 was slightly above the range hence they have poor mechanical strength. All the formulations were disintegrated within 3 min. wetting time is based on the tablet's inner structure as well as the hydrophilicity of the excipients. The wetting time for all the formulations was fast which may be due to the high water absorption capacity of the croscarmellose sodium which is highly hydrophilic in nature.

Table 3: Post compression results

\begin{tabular}{|c|c|c|c|c|c|c|c|}
\hline Formulation & $\begin{array}{l}\text { Weight } \\
\text { variation (mg) }\end{array}$ & $\begin{array}{l}\text { Hardness } \\
(\mathrm{Kg} / \mathrm{cm} 2)\end{array}$ & $\begin{array}{l}\text { Friability } \\
(\% w / w)\end{array}$ & $\begin{array}{l}\text { Thickness } \\
\text { (mm) }\end{array}$ & $\begin{array}{l}\text { Drug content } \\
(\%)\end{array}$ & $\begin{array}{l}\text { Disintegration time } \\
\text { (min) }\end{array}$ & $\begin{array}{l}\text { Wetting time } \\
\text { (s) }\end{array}$ \\
\hline F1 & $526.53 \pm 2.24$ & $2.83 \pm 0.26$ & $0.95 \pm 0.11$ & $5.14 \pm 0.001$ & $97.58 \pm 3.02$ & $2.34 \pm 0.089$ & $62.33 \pm 2.52$ \\
\hline $\mathrm{F} 2$ & $545.49 \pm 2.55$ & $3.08 \pm 0.2$ & $0.93 \pm 0.04$ & $5.20 \pm 0.001$ & $95.23 \pm 7.14$ & $2.89 \pm 0.185$ & $63.33 \pm 2.52$ \\
\hline F3 & $547.28 \pm 2.50$ & $3.42 \pm 0.4$ & $0.73 \pm 0.04$ & $5.18 \pm 0.002$ & $98.92 \pm 4.45$ & $2.61 \pm 0.460$ & $52.00 \pm 2.00$ \\
\hline $\mathrm{F} 4$ & $270.94 \pm 1.49$ & $2.58 \pm 0.2$ & $1.14 \pm 0.07$ & $2.07 \pm 0.002$ & $95.1 \pm 6.2$ & $1.28 \pm 0.332$ & $32.33 \pm 1.53$ \\
\hline F5 & $272.91 \pm 2.62$ & $2.75 \pm 0.27$ & $1.4 \pm 0.09$ & $2.22 \pm 0.003$ & $96.11 \pm 4.7$ & $2.03 \pm 0.176$ & $37.00 \pm 1.00$ \\
\hline F6 & $275.34 \pm 2.04$ & $2.41 \pm 0.49$ & $1.17 \pm 0.15$ & $2.30 \pm 0.003$ & $95.67 \pm 6.5$ & $1.74 \pm 0.618$ & $31.66 \pm 2.08$ \\
\hline F7 & $306.35 \pm 2.92$ & $2.25 \pm 0.27$ & $3.71 \pm 0.92$ & $2.34 \pm 0.003$ & $95.88 \pm 5.82$ & $1.71 \pm 0.404$ & $47.33 \pm 2.08$ \\
\hline
\end{tabular}

(Results were expressed in mean $\pm S D, n=3$ )

\section{FTIR studies}

The results obtained confirms the purity of cinnarizine since the peak values obtained were similar as the characteristic peak values. Fig. (4) Show the results of the FTIR analysis of pure drug as well as the drug mixed with each excipient separately at the fixed ratio. From the results, it is evident that there is no drug excipient incompatibilities between the drug (cinnarizine) and the excipients (Neusilin US2, Aerosil 200, propylene glycol and croscarmellose sodium) when the drug is analyzed with each excipient separately.

To justify this results, FTIR analysis was also carried out on the liquidsolid compact (after direct compression), and comparison was done with the spectra of pure cinnarizine as shown in fig. (5). The appearance of all the characteristic peak and absence of any new peaks in the IR spectra of liquid-solid compact, F3 shows the absence of any chemical interaction between the cinnarizine and the excipients [23]. 


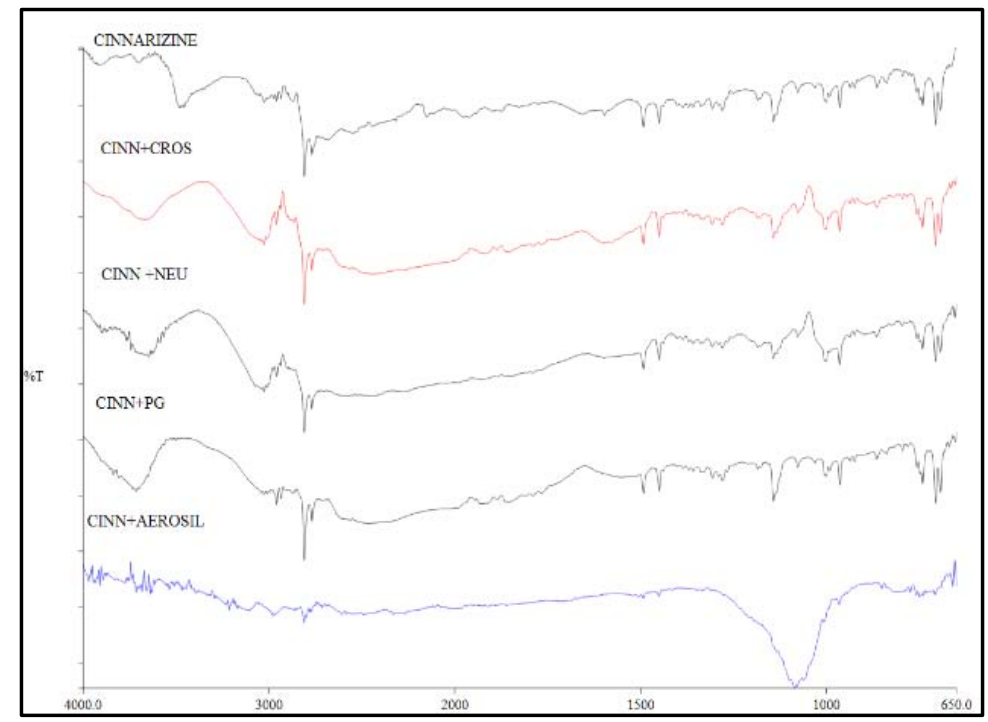

Fig. 4: Split view of IR Spectra of pure drug and mixture of pure drug and excipients in equal ratio

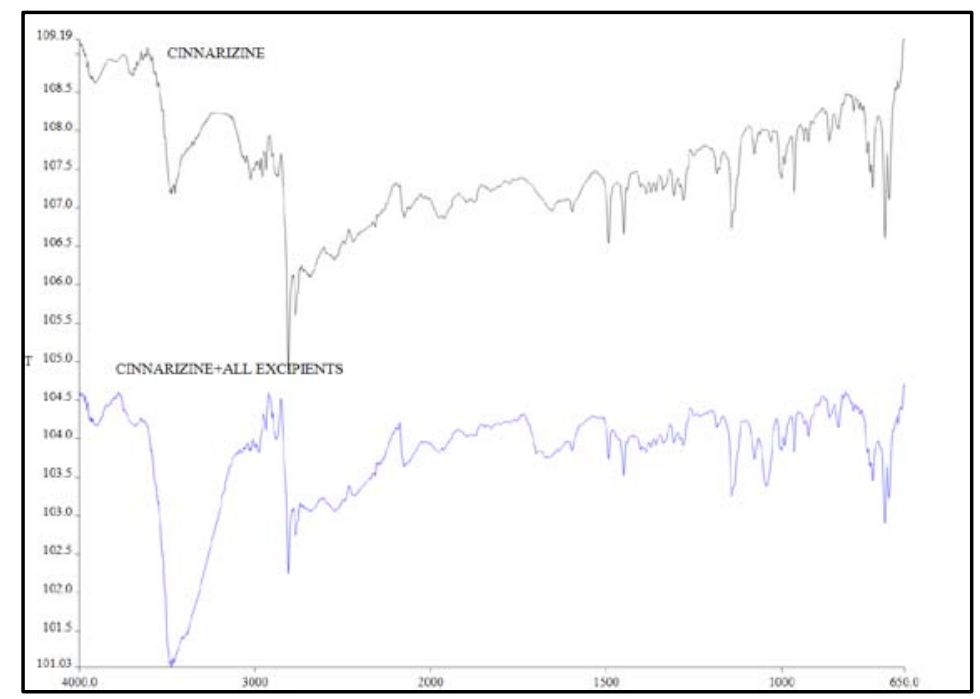

Fig. 5: Comparison of IR spectra between the pure drug and the formulated liquid-solid compact (F3)

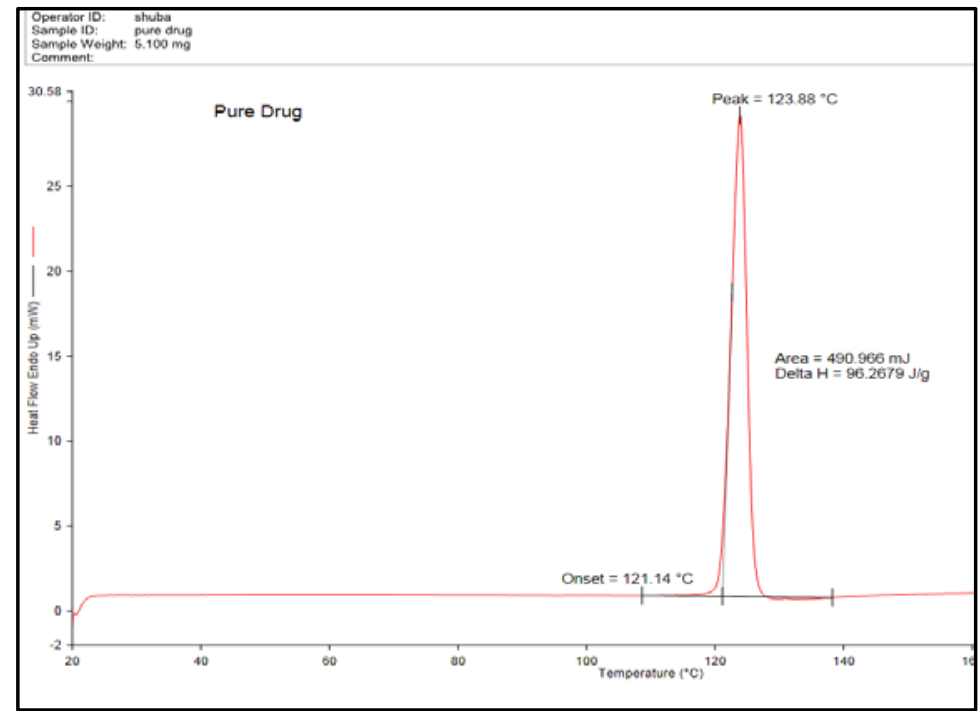

Fig. 6: DSC thermogram of cinnarizine (pure drug) 


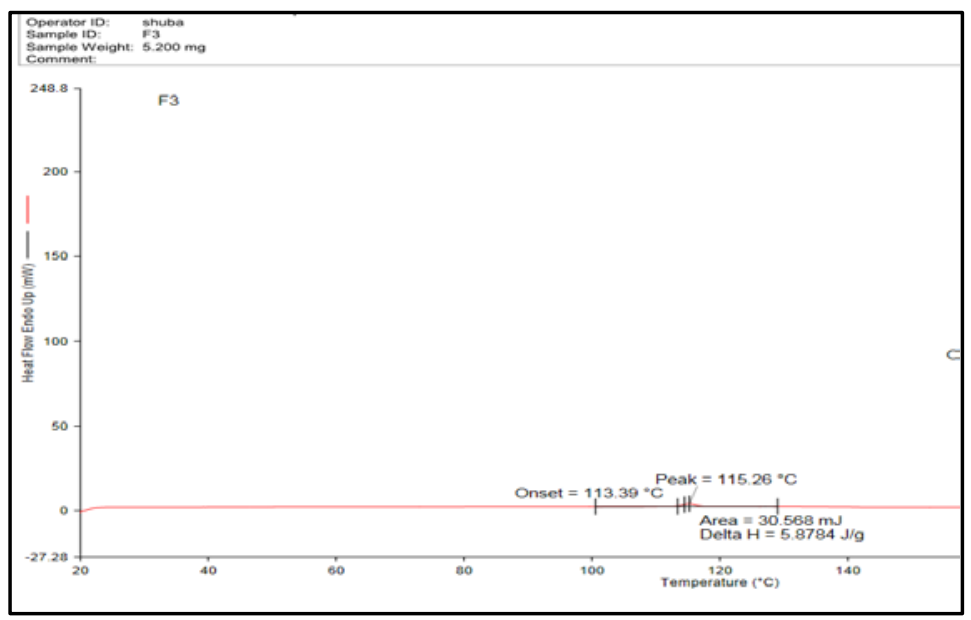

Fig. 7: DSC thermogram of liquid-solid compact (F3)

\section{DSC studies}

DSC of pure cinnarizine showed a characteristic, sharp endothermic peak at $123.88{ }^{\circ} \mathrm{C}$ which is associated with the melting point of the drug and indicates the crystalline nature of cinnarizine as shown in fig. 6.

From the fig. 7 we can see that the thermogram of F3 shows a complete loss of cinnarizine peak indicating a change to the amorphous state of the drug. The results obtained justifies that the cinnarizine in the solid liquid formulations has lost its crystalline structure and the drug is present in its molecularly dispersed state. Thus, we can conclude that cinnarizine has been completely solubilized in Propylene Glycol [24].

\section{In vitro dissolution studies}

All the seven formulations were subjected for in vitro dissolution to study the drug release profile using the dissolution apparatus. From fig. (8), it was observed that liquid-solid compact formulations (F1F6) exhibited enhanced dissolution profile when compared to the marketed formulation (F7). This is evident because the formulations with the drug dissolved in the propylene glycol causes the drug to be molecularly dispersed resulting in increased surface area for wetting and subsequent dissolution $[25,26]$. The percentage of drug release of F3 was found to be the highest with a value of $88.11 \%$, and the lowest percentage of drug release was from the F7 which represents the conventional marketed tablet with a cumulative percentage value of $44.07 \%$ at $120 \mathrm{~min}$ (fig. 9).

The concentration of the drug in the liquid medication also plays an integral part in the drug release profile. When the dissolution profiles of F3 (10\%) and F6 (20\%) are compared, there is a significant difference observed. The dissolution rate of the solid liquid compacts increases with the decrease in concentration of the drug in the liquid medication. This is because in a highly concentrated formulation, the amount of drug is available in the molecularly dispersed state is lower compared to the less concentrated formulation $[27,28]$.

Besides, the role of R-value which resembles the powder excipient ratio also influences the in vitro drug release profile. Comparisons have been done between the formulations with the same concentrations but different R-value. F3 which has a higher R-value of 20 shown to be having a better dissolution rate of $88.11 \%$ at 120 min compared to $\mathrm{F} 1$ which released $74.18 \%$ due to the lower R-value of just 5 . Generally, the solid liquid compacts with high R-value comprised of the relatively large amount of powder admixture (carrier and coating materials) and the amount of non-volatile solvent available per powder substrate is relatively larger. Hence the solid liquid compacts with high $\mathrm{R}$ values showed a better dissolution profile $[29,30]$.

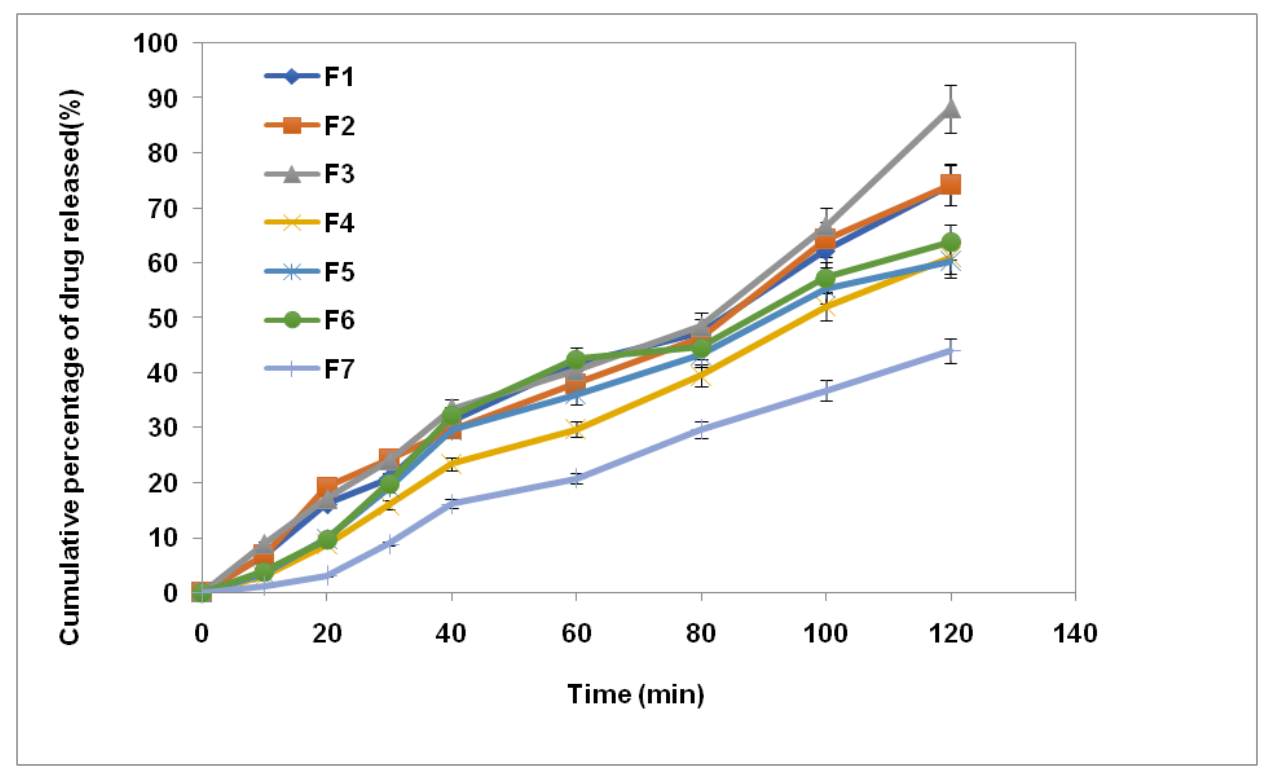

Fig. 8: Dissolution profile of F1-F7 in $0.1 \mathrm{~N} \mathrm{HCl}$ (data expressed as a mean $\pm \mathrm{SD}, \mathrm{n}=3$ ) 


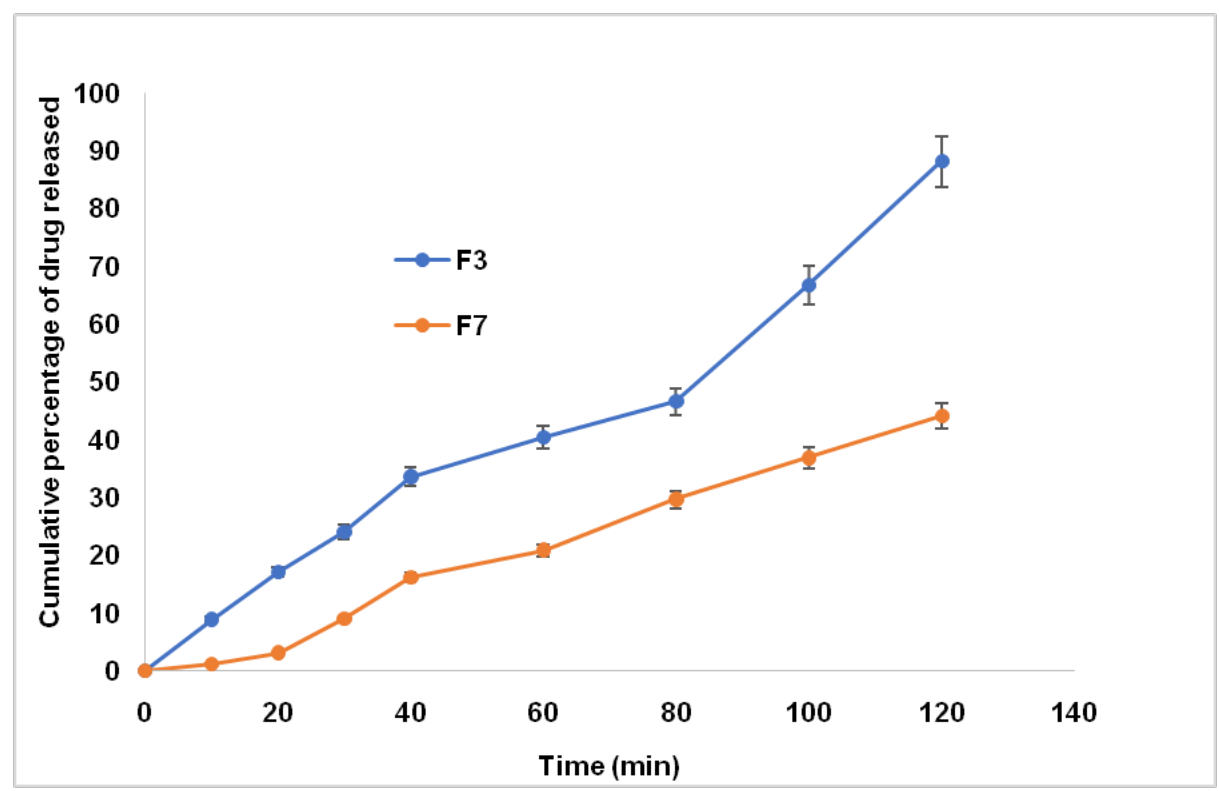

Fig. 9: Comparison of dissolution profile of F3 (Optimized liquid-solid compact) an F7 (conventional tablet), (data expressed as a mean $\pm S D, n=3$ )

\section{CONCLUSION}

The solid liquid compacts were successfully formulated using the appropriate amount of non-volatile solvent, carrier and coating material as well as the disintegrant which were calculated based on the loading factor and the liquid retention potential of carrier and coating material. The results of the various evaluation tests show that the solid liquid compacts produced were within acceptable limits. The dissolution rate results show that the main objective of this research has been met because there is a marked improvement in the dissolution profile of the F3 which higher carrier to coating ratio and lower drug concentrations when compared to that of the conventional tablet. Hence, it is concluded that liquid-solid compact technique is a novel approach that can be employed to increase the solubility and dissolution rate of cinnarizine.

\section{ACKNOWLEDGMENT}

The authors thank Kotra Pharma Sdn. Bhd., Malaysia for providing with cinnarizine as a gift sample.

\section{AUTHORS CONTRIBUTIONS}

All the authors have contributed equally

\section{CONFLICT OF INTERESTS}

The authors declare no conflict of interests

\section{REFERENCES}

1. Raghuvanshi S, Pathak K. Recent advances in delivery systems and therapeutics of cinnarizine: a poorly water-soluble drug with absorption window in the stomach. J Drug Delivery 2014;1-15. http://dx.doi.org/10.1155/2014/479246.

2. Savjani KT, Gajjar AK, Savjani JK. Drug solubility: importance and enhancement techniques. ISRN Pharm 2012;1-10. http://dx.doi.org/10.5402/2012/195727.

3. Spireas S, Bolton M. Liquisolid systems and methods of preparing same, U. S. Patent 5, 968, 550; 1999.

4. Sanjayamitra PVSS, Ganesh GNK. Dissolution and solubility enhancement strategies: current and novel prospectives. J Crit Rev 2018;5:1-10.

5. Jain H, Pasha TY, Bais CS, Bhandari A. Formulation and characterization of liquisolid tablets of valsartan for improvement of dissolution rate. Asian J Pharm Clin Res 2014;7:21-6.

6. Sisinthy SP, Sarah CYL, Nalamolu KR. Optimization of coconut oil based self-micro emulsifying drug delivery systems of olmesartan medoxomil by simplex centroid design. Int J Appl Pharm 2016;8:47-52.

7. Prajapati ST, Bulchandani HH, Patel DM, Dumaniya SK, Patel CN Formulation and evaluation of liquisolid compacts for olmesartan medoxomil. J Drug Delivery 2013;1-9. http://dx.doi.org/10.1155/2013/870579

8. Karmarkar AB, Gonjari ID, Hosmani AH, Dhabale PN, Bhise SB. Liquisolid tablets: a novel approach for drug delivery. Int J Health Res 2009;2:45-50.

9. Khan A, Agrawal S. Formulation and evaluation of lumefantrine capsule prepared by using liquisolid technique. Int J Curr Pharm Res 2018; 10:43-50.

10. Dalvi PB, Ingale PR. Liquisolid technique: an approach for enhancement of solubility. World J Pharm Pharm Sci 2014;3:434-46.

11. Anil A, Thomas L, Sudheer P. Liquisolid compacts: an innovative approach for dissolution enhancement. Int J Pharm Pharm Sci 2018;10:1-7.

12. Hussain MA, Gorre M, Rao TR, Anjum M. Preparation and evaluation of nilvadipne liquisolid compacts. Int J Pharm Pharm Sci 2014;6:1-8.

13. Jassim ZE. Formulation and evaluation of furosemide liquisolid compact. Int J Appl Pharm 2017;9:39-48.

14. Naveen C, Narra N, Rao TR. Preparation and characterization of liquidsolid compacts for improved dissolution of telmisartan. J Drug Delivery 2014;1-10 http://dx.doi.org/10.1155/2014/692793

15. Uddin MS, Mamun AA, Tasnu T, Asaduzzaman M. In-process and finished products quality control tests for pharmaceutical tablets according to pharmacopoeias. J Chem Pharm Res 2015; 7:180-5.

16. Rajab NA. Preparation and in vitro evaluation of lacidipine oral liquid solid tablet as an approach of solubility and dissolution rate enhancement. Int J Appl Pharm 2018;10:145-53.

17. Haritha B. A review on an evaluation of tablets. J Formulation Sci Bioavailability 2017;1:1-5.

18. Kapoor D, Lad C, Vyas R, Patel M. Formulation development, optimization and in vitro characterization of liquisolid compacts of an oxicam derivative. J Drug Delivery Ther 2016;6:64-70.

19. Paus R, Hart E, Ji Y, Sadowski G. Solubility and caloric properties of cinnarizine. J Chem Eng Data 2015;60:2256-61.

20. Patil DM, Wagh KR, Chaudhari SS, Bairagi VA, Patil VR. Formulation development and evaluation of orodispersible tablet of cinnarizine solid dispersion. Indo Am J Pharm Sci 2017;4:910-25. 
21. Dias RJ, Mali KK, Ghorpade VS, Havaldar VD, Mohite VR Formulation and evaluation of carbamazepine liquisolid compacts using novel carriers. Indian J Pharm Edu Res 2017;51(2S):69-77.

22. Patel BB, Shah CN. Recent research on liquisolid technology for solubility enhancement-a review. Int J Adv Pharm 2016;5:1-7.

23. Gubbi SR, Jarag R. Formulation and characterization of atorvastatin calcium liquisolid compacts. Asian J Pharm Health Sci 2010;5:50-60.

24. Akbari J, Saeedi M, Semnani KM, Ghadi ZS, Hosseini SS. Improving the dissolution properties of spironolactone using a liquisolid technique. Pharm Biomed Res 2015;1:59-70.

25. Javadzadeh Y, Siahi MR, Asnaashari S, Nokhodchi A. An investigation of physicochemical properties of piroxicam liquisolid compacts. Pharm Dev Technol 2007;12:337-43.
26. Kamble PR, Shaikh KS, Chaudhari PD. Application of liquisolid technology for enhancing solubility and dissolution of rosuvastatin. Adv Pharm Bull 2014;4:197-204.

27. Balaji A, Umashankar MS, Kavitha B. Liquisolid technology-a latest review. Int J Appl Pharm 2014;6:11-9.

28. Gavali SM, Pachrane SS, Sankpal SV, Jadhav KR, Kadam VJ. Liquisolid compact: a new technique for enhancement of drug dissolution. Int J Res Pharm Chem 2011;1:705-13.

29. Nokhodchi A, Javadsadeh Y, SIahi Shadbad MR, Barzegar Jalali $M$. The effect of type and concentration of vehicles on the dissolution rate of a poorly soluble drug (indomethacin) from liquisolid compacts. J Pharm Pharm Sci 2005;8:18-25.

30. Burra S, Yamsani M, Vobalaboina V. The liquisolid technique: an overview. Braz J Pharm Sci 2011;47:475-82. 